\title{
OVERWEIGHT IN CHILDREN AND ADOLESCENTS: CLINICAL VARIABLES, MOTIVATIONAL AND FAMILY PSYCHOSOCIAL RISK
}

\section{Maria Camila Buarraj Gomes}

Pontifícia Universidade Católica de Campinas - PUC-Campinas/SP, Brasil.

\section{André Luiz Monezi Andrade}

Pontifícia Universidade Católica de Campinas - PUC-Campinas/SP, Brasil.

\section{Wagner de Lara Machado}

Pontifícia Universidade Católica do Rio Grande do Sul - PUCRS, Porto Alegre/RS, Brasil.

\section{Sônia Regina Fiorim Enumo}

Pontifícia Universidade Católica de Campinas - PUC-Campinas/SP, Brasil.
Autor correspondente

Maria Camila Buarraj Gomes

maria-camila@hmcp.puc-campinas.edu.br

\begin{abstract}
This study evaluated the relationships between anthropometric, dietary, motivational, and psychosocial variables among children and adolescents with overweight and non-alcoholic fatty liver disease (NAFLD). We evaluated 45 participants (6-17 years) in anthropometric terms, nutritional consumption, motivation for treatment, and family psychosocial risk by using statistical analyses (Student's $t$-Test or Chi-Square). It was detected that $37.8 \%$ of the families had a high psychosocial risk, $82.2 \%$ were obese, $33.3 \%$ with NAFLD, high motivation (93.3\%), but low adherence to treatment (2.4\%). Participants with NAFLD presented higher psychosocial risk, significantly greater obesity severity, waist and neck circumference, and Body Mass Index. They reported lower adherence to treatment, high carbohydrate consumption, ultra-processed products, high energy density, and low fiber, with poor nutritional quality. Interventions should consider the motivation for treatment and psychosocial risks, especially in cases with NAFLD.
\end{abstract}

KEY WORDS: Pediatric obesity; Fatty liver; Risk factors; Anthropometry; Food consumption.

\section{EXCESSO DE PESO ENTRE CRIANCYAS E ADOLESCENTES: ASPECTOS CLÍNICOS, MOTIVACIONAIS E RISCO PSICOSSOCIAL FAMILIAR}

RESUMO: Este estudo analisou as relações entre variáveis antropométricas, dietéticas, motivacionais e psicossociais em crianças e adolescentes com excesso de peso e esteatose hepática não alcoólica (EHNA). Avaliou-se 45 pacientes (6-17 anos) em termos antropométricos, de consumo nutricional, motivação para o tratamento e risco psicossocial familiar, com análises estatísticas (Teste $t$ de Student ou Qui-Quadrado). Observou-se que 37,8\% das famílias tinham alto risco psicossocial, $82,2 \%$ da amostra estavam obesos, 33,3\% com EHNA, alta motivação $(93,3 \%)$, mas uma baixa adesão ao tratamento $(2,4 \%)$. Os participantes com EHNA apresentaram maior risco psicossocial, significativamente maior gravidade da obesidade, circunferência da cintura e pescoço, e Índice de Massa Corporal. Eles relataram menor adesão ao tratamento, alto consumo de carboidratos, produtos ultraprocessados, de alta densidade energética e com baixa quantidade de fibras, com pior qualidade nutricional. As intervenções devem considerar a motivação para o tratamento e os riscos psicossociais, especialmente nos casos com EHNA.

PALAVRAS-CHAVE: Obesidade pediátrica; Fígado gorduroso; Fator de risco; Antropometria; Consumo alimentar. 


\section{INTRODUCTION}

Overweight and obesity is a worldwide public health problem, with an estimated 603.7 million obese adults and 107.7 million obese children worldwide ${ }^{1}$. In Brazil, there is also an increase in overweight in all age groups and social classes, especially among male adolescents. Between 5 and 9 years old, 33.5\% are overweight ${ }^{2}$. In the Study of Cardiovascular Risks in Adolescents (ERICA), the highest prevalence of overweight was in the Southern Region of the country (12.5\%), and the lowest was in the Northern; finding $74 \%$ of adolescents spending two or more hours daily in front of the screens and $56.6 \%$ having meals in front of the television ${ }^{3}$.

These findings are concerning because childhood obesity is one of the key predictors of adult obesity, and some comorbidities, such as hypertension, type 2 diabetes and insulin resistance, all associated with non-alcoholic fatty liver disease (NAFLD), with worsening quality of life $e^{4}$ ${ }^{5}$. With this in mind, the identification of factors associated with weight gain in childhood and adolescence is essential to develop more effective prevention programs.

NAFLD has reached epidemic proportions in the last decades, in parallel with the increasing rates of overweight in children and adolescents, with an average prevalence of between $15 \%$ and $42 \%$ in the obese pediatric population $^{6}$. In Brazil, data from a nationwide study indicated that those adults and adolescents with Type 1 diabetes showed a high prevalence of NAFLD (32.3\%), mainly among adult population? ${ }^{7}$. Particularly in the city of Campinas, Brazil, the prevalence of $20 \%$ of NAFLD was found in a sample of 79 obese adolescents ${ }^{8}$.

The anthropometric variables most associated with NAFLD were higher body mass index (BMI) and waist circumference above the reference standard which is an indicative of visceral adiposity ${ }^{9}$. Dietary indicators highlight excessive calorie intake and a high proportion of carbohydrates about total caloric intake ${ }^{4}$. In one hundred adolescents, Santos and Ribas ${ }^{10}$ found that 31\% were overweight, $65 \%$ inactive, a high intake of protein and sodium, and consumption below daily recommendations for calcium, fiber, and monounsaturated fats, as well as food inadequacies in lipid and calcium intake.
Despite the NAFLD's genetic basis, there are other risk factors such as environmental, western diet, ultra-processed foods, lack of regular physical activity, obesity, metabolic syndrome and insulin resistance ${ }^{11}$. The treatment and prevention of NAFLD primarily consist of the re-education of eating habits and regular physical activity for weight reduction ${ }^{4}$.

Herein lies the difficulty of adherence treatment, as overweight is a condition associated with multiple factors, and among them is the motivation for treatment. In this sense, in the one-year longitudinal study of Dalla et al. ${ }^{12}$ the authors observed the motivation factor almost doubled the odds of favorable outcomes, especially among younger participants.

Family psychosocial factors may also contribute, with the socioeconomic level interacting with race/ ethnicity and birth weight, among other relationships. It is a framework that also involves the family and its psychosocial risk conditions, as obesity is associated with lower parental schooling, poverty, lower socioeconomic status, greater social vulnerability, poor access to health and education, in other words, stressful conditions ${ }^{13}$.

In light of this highly complex setting in the treatment of NAFLD and overweight in childhood and adolescence, more studies are necessary to assess the relationship between NAFLD and other variables in this age group. This study aimed to investigate clinical, anthropometric and dietary variables associated with NAFLD diagnosis of overweight children and adolescents in outpatient care, as to their relationships with family psychosocial risk and motivation for treatment.

It was hypothesized that the prevalence of NAFLD among participants would range from $20 \%$ until $40 \%$, according to the literature ${ }^{8,13}$. It was also considered likely that this group with NAFLD presented less healthy diet and physical activity habits, considering that part of the problem is associated with the family lifestyle ${ }^{13}$. Thus, there is a possible association with a greater family psychosocial risk, as this tends not to favor practicing healthy behaviors ${ }^{13}$. Finally, given the difficulty of weight control, it was hypothesized that participants with NAFLD would have less motivation for the treatment and the practice of physical activities ${ }^{12}$. 


\section{METHODOLOGY}

\section{PARTICIPANTS}

A convenience sample of 45 participants (19 children and 26 adolescents) between 5 and 17 years of age (Mage $=11.3, S D=2.96$ ) was composed, having $57.8 \%$, in addition to those responsible. All participants were diagnosed with overweight, according to the $\mathrm{WHO}$ criteria ${ }^{14}$, being on clinical follow-up at the endocrinology outpatient clinic at a university hospital in a city of São Paulo State, for six months to one year.

The inclusion criteria were: having a diagnosis of overweight, five to 18 years of age, having signed the Consent Form, and the Free Informed Consent Form by the parents/guardians. Cases of diseases leading to weight gain that were excluded; noticeable delay in neuromotor development; viral or congenital hepatitis; history of alcohol use and not having the abdominal ultrasound examination for the diagnosis of NAFLD.

\section{INSTRUMENTS}

Characterization Profile with the following data:

(i) personal data obtained in the medical record or from the health professional - sex, age, schooling, diagnostic hypotheses and presence of xanthoma/ xanthelasma;

(ii) Laboratorial parameters ${ }^{15}$ - total cholesterol lipid profile, LDL cholesterol, HDL cholesterol, and triglycerides), fasting glycaemia and liver function tests (AST- aspartate aminotransferase and ALT- alanine aminotransferase), with results classified by the $\mathrm{V}$ Brazilian Guidelines on Dyslipidemias and Prevention of Atherosclerosis by the Brazilian Society of Cardiology ${ }^{16}$; and the NAFLD ultrasound report, provided by the hospital, by Hepatorenal Index ("light", "moderate" and "severe" degrees). The criteria to NAFLD was the difference of the echogenicity between the liver and the renal cortex, this procedure is kwon as hepatorenal index ${ }^{15}$.

(iii) anthropometric evaluation - weight, height, waist and neck circumference', BMI (weight/squared height) compared to $\mathrm{WHO}$ criteria $^{14}$ for the range of five to 19 years;

(iv) routine - time spent on electronic devices and study; a place where meals are eaten, the frequency of meals away from home, intestinal habit and pattern of water intake;

(v) Diet - 24-hour recall, listing the foods and beverages ingested the previous day, allowing the calculation of total caloric value, the percentage of macronutrients (carbohydrates, lipids, and proteins) and fiber intake, using Nut Win software, version 15.0. For the daily calorie intake, it was used the Recommended Dietary Allowances protocol ${ }^{17}$;

Food Frequency Questionnaire, quantifying the consumption and frequency of certain food intake, in a given period, by closed questions, analyzed by the Food Pyramid ${ }^{18}$.

(vi) Physical activity data - traveling time to school, physical activities inside and outside the school, and the perception of parents/guardians about the participation and interest of the children in physical activities.

Psychosocial Assessment Tool 2.0 (PAT 2.0) Psychosocial Assessment Tool $^{19}$ - assesses the psychological and social impact of the disease. It has seven subscales: 1) Family structure and sources, 2) Social support, 3) Problems with the child, 4) Problems with siblings, 5) Family problems, 6) Reaction to stress, and 7) Family beliefs, classified under Universal, Directed or Clinical family risk level, each with treatment recommendations to support family adaptation.

Instruments for evaluating motivation for treatment - four elaborate questions, having two relating to being motivated or not to follow the diet and practicing physical activities, and two about how effectively this is done, on a four-point scale $(1=$ "not at all" to $4=$ "very"). A pilot study was conducted on five children and five adolescents not participating in the study to verify their adequacy.

Materials - platform scale and vertical stadiometer, belonging to the Service, and a flexible tape measure of the principal researcher with training and experience in the area of Hospital Nutrition.

\section{PROCEDURES}

After the approval of the University Research Ethics Committee ( $\mathrm{n}^{\mathrm{O}}:$ 1.799.885), the data collection was carried out individually in the presence of the guardian after the participants' medical consultation. The 
average time to collect all information was 30 minutes. All anthropometric indices were collected twice (double check), considering the average of the measurements. All were barefoot and wore light clothing, standing, upright, abdomen relaxed, arms extended along their sides, and their feet separated by a distance of $25-30 \mathrm{~cm}$. At the end of the data collection, participants received an explanatory leaflet on healthy eating and habits.

\section{DATA ANALYSIS}

Continuous variables were transformed into Z-scores to normalize the data, tested by the Shapiro Wilk test, followed by Student's t-test. The nominal variables were analyzed by the Chi-square test or Fisher's exact test (significance of 5\%). Statistical Package for Social Science (SPSS), version 19 was used.

\section{RESULTS}

All participants were overweight, $82.2 \%$ were considered obese, and 33.3\% were detected with NAFLD. Table 1 indicates the participants' routines with NAFLD (G1-NAFLD) and without NAFLD (G2), indicating that there were no significant differences between the groups for any of the variables.

Comparatively, G1-NAFLD exhibited higher BMI, waist and neck circumference, triglyceride and carbohydrate intake, and more than $60 \%$ of inadequate water intake (below the recommendation) (G2 $=46.7 \%$ ). The frequency of intestinal functioning was one or more times/day for both groups (Table 2).

G1-NAFLD presented similar consumption to the total sample, with ultra-processed foods and higher energy density, such as sausages, ice cream, filled cookies and industrialized cakes with high consumption percentages in the frequency of "one to two times a week." High consumption of processed juices, filled cookies, fried foods in general and vegetables was also exhibited (Figure 1).

About those without NAFLD (G2), an inversion profile to the recommendations was also presented, with consumption of "one to two-times without or greater than five-times without" foods with high energy density and low nutritional value, such as fried foods, sausages, industrialized cakes, and chips. The daily consumption of processed juices and consumption far below the Food Pyramid recommendation levels 1 and 2 stands out. Besides, G2 presented high consumption of salted snacks like "chips" and sausages, and lower consumption of vegetables.

Of a total of 45 families, more than $70 \%$ were at psychosocial risk: $37.8 \%$ at high risk (Clinical) and $33.3 \%$ at moderate risk (Target) and 28.9\% at low risk, indicated for preventive intervention at Universal level. The PAT 2.0's domain with the highest mean for both groups was Child Problems, highlighting the Family and Resources Structure, and Parents' Stress Reactions, with a high score, representing contexts that put the family at a higher vulnerability situation. Comparatively, the G1NAFLD presented higher scores, except in the Problems of the Siblings domain; with significant differences in the areas of Child Problems and Family Problems (Table 3).

Most of the family $(60 \%)$ were obese, being $24.4 \%$ in the parents and $6.7 \%$ in the siblings. These cases presented comorbidities, arterial hypertension, and diabetes mellitus, being $51.1 \%$ in close relatives (parents, mothers or siblings), with diagnoses of diseases associated with obesity, especially in the parents (48.9\%). The majority of participants reported being motivated for dietary treatment $(93.3 \%)$; however, $57.1 \%$ reported doing "little" of what is oriented in the nutritional conduct; $15.6 \%$ did "nothing"; and 2.4\% thought they had "high" adherence to the proposed treatment. In G1-NAFLD, $86.7 \%$ of the participants reported being motivated for treatment, of which $53.8 \%$ said they had "low" attitude towards the proposed treatment. In G2, there was also a high percentage of motivation to the proposed treatment (96.7\%); but 58.6\% reported "low" attitude toward dietary treatment (Table 4).

The majority of G1-NAFLD (52.2\%) felt unmotivated to practice physical activity, unlike the 63.3\% motivated in G2. Among those who stated that they were motivated in G1-NAFLD ( $\mathrm{n}=7$ ), $42.9 \%$ admitted "low" attitude to exercise; in G2, 42.1\% reported having "moderate" physical activity (Table 4). It was detected a significant effect between the motivation to practice physical activity and the psychosocial risk $(p<0.05)$, which means that those who were not motivated to practice physical exercise were at the level of moderate or clinical psychosocial risk $(p<0.05)$. 
Table 1. Routine of overweight children and adolescents, with and without Non Alcoholic Fatty Liver Disease (NAFLD)

\begin{tabular}{|c|c|c|c|c|c|c|c|c|c|}
\hline & \multicolumn{2}{|c|}{$\begin{array}{l}\text { G1-NAFLD } \\
(\mathrm{n}=15)\end{array}$} & \multirow[t]{2}{*}{ CI 95\% } & \multicolumn{2}{|c|}{$\begin{array}{c}\mathrm{G} 2 \\
(\mathrm{n}=30)\end{array}$} & \multirow[t]{2}{*}{ CI $95 \%$} & \multirow[t]{2}{*}{ Test } & \multirow[t]{2}{*}{$p$} & \multirow[t]{2}{*}{$\begin{array}{c}\text { Effect } \\
\text { size }\end{array}$} \\
\hline & $N$ & $\%$ & & $N$ & $\%$ & & & & \\
\hline Daily study time (hours) & & & & & & & $\chi_{(1)=}^{2} 0.49$ & 0.48 & 0.09 \\
\hline Up to 1 hour & 14 & 93.3. & {$[0.68-0.99]$} & 25 & 86.2 & {$[0.69-0.96]$} & & & \\
\hline 2 or more & 1 & 6.7 & {$[0.01-0.31]$} & 4 & 13.8 & {$[0.03-0.30]$} & & & \\
\hline TV time (hours) & & & & & & & $\chi_{(2)}^{2}=2.64$ & 0.26 & 0.24 \\
\hline Up to 1 hour & 2 & 13.3 & {$[0.01-0.04]$} & 7 & 23.3 & {$[0.09-0.42]$} & & & \\
\hline 2 to 3 & 4 & 26.7 & {$[0.07-0.55]$} & 12 & 40 & {$[0.22-0.59]$} & & & \\
\hline 4 or more & 9 & 60 & {$[0.32-0.83]$} & 11 & 36.7 & {$[0.19-0.56]$} & & & \\
\hline Meal location & & & & & & & $\chi_{(1)}^{2}=0.31$ & 0.57 & 0.08 \\
\hline Table & 7 & 46.7 & {$[0.21-0.73]$} & 12 & 40 & {$[0.22-0.59]$} & & & \\
\hline Living room/Bedroom/TV & 8 & 53.3 & {$[0.26-0.78]$} & 18 & 60 & {$[0.40-0.77]$} & & & \\
\hline Physical activity level & & & & & & & $\chi_{(1)}^{2}=0.04$ & 0.83 & 0.03 \\
\hline Active & 8 & 53.3 & {$[0.26-0.78]$} & 15 & 50 & {$[0.31-0.68]$} & & & \\
\hline Little active & 7 & 46.7 & {$[0.21-0.73]$} & 15 & 50 & {$[0.31-0.68]$} & & & \\
\hline \multicolumn{2}{|c|}{ Physical activity interest level } & & & & & & $\chi_{(1)}^{2}=0.21$ & 0.64 & 0.06 \\
\hline Interested & 11 & 73.4 & {$[0.45-0.92]$} & 20 & 66.7 & {$[0.47-0.82]$} & & & \\
\hline Little interest & 4 & 26.6 & {$[0.07-0.55]$} & 10 & 33.3 & {$[0.17-0.52]$} & & & \\
\hline Practices sport in school? & & & & & & & $\chi_{(1)}^{2}=0.33$ & 0.56 & 0.08 \\
\hline Yes & 12 & 80 & {$[0.51-0.95]$} & 26 & 86.7 & {$[0.69-0.96]$} & & & \\
\hline No & 3 & 20 & {$[0.04-0.48]$} & 4 & 13.3 & {$[0.03-0.30]$} & & & \\
\hline \multicolumn{2}{|c|}{ Practices sport out of school? } & & & & & & $\chi_{(1)}^{2}=0.04$ & 0.83 & 0.03 \\
\hline Yes & 7 & 46.7 & {$[0.21-0.73]$} & 15 & 50 & {$[0.31-0.68]$} & & & \\
\hline No & 8 & 53.3 & {$[0.26-0.78]$} & 15 & 50 & {$[0.31-0.68]$} & & & \\
\hline
\end{tabular}

Table 2. Anthropometric, biochemical and alimentary data of overweight children and adolescents, with and without Non-Alcoholic Fatty Liver Disease (NAFLD)

(Continua)

\begin{tabular}{|c|c|c|c|c|c|c|c|c|c|}
\hline & \multicolumn{2}{|c|}{$\begin{array}{c}\text { G1-NAFLD }(\mathrm{n}= \\
15)\end{array}$} & \multirow[t]{2}{*}{ CI 95\% } & \multicolumn{2}{|c|}{$\mathbf{G} 2(\mathrm{n}=30)$} & \multirow[t]{2}{*}{ CI 95\% } & \multirow[t]{2}{*}{ Test } & \multirow[t]{2}{*}{$p$} & \multirow[t]{2}{*}{$\begin{array}{c}\text { Effect } \\
\text { size }\end{array}$} \\
\hline & $M$ & $S D$ & & $M$ & $S D$ & & & & \\
\hline \multicolumn{10}{|l|}{ Anthropometric evaluation } \\
\hline Weight (Kg) & 77.5 & 27.7 & {$[63.6-91.4]$} & 70.9 & 26.2 & {$[61.1-80.7]$} & $t_{(43)}=0.78$ & 0.43 & 0.11 \\
\hline Height (cm) & 151.9 & 3.1 & {$[144.5-159.3]$} & 153.4 & 2.8 & [148.1-158.6] & $t_{(43)}=-0.32$ & 0.10 & 0.06 \\
\hline BMI $\left(\mathrm{Kg} / \mathrm{m}^{2}\right)$ & 32.8 & 2.0 & {$[29.6-36.1]$} & 29.0 & 0.9 & {$[26.7-31.3]$} & $t_{(43)}=1.95$ & $* * *$ & 0.08 \\
\hline Waist circumference $(\mathrm{cm})$ & 99.7 & 4.4 & {$[92.1-107.5]$} & 92.3 & 2.5 & {$[86.8-97.7]$} & $t_{(43)}=1.60$ & $* * *$ & 0.05 \\
\hline Neck circumference $(\mathrm{cm})$ & 38.5 & 1.1 & {$[36.2-40.8]$} & 34.9 & 0.8 & {$[33.2-36.5]$} & $t_{(43)}=2.60$ & $* * *$ & 0.13 \\
\hline \multicolumn{10}{|l|}{ Biochemical indicators $^{(a)}$} \\
\hline Total cholesterol (mg/dL) & 157.2 & 34.3 & {$[139.7-174.6]$} & 169.9 & 33.2 & {$[157.6-182.6]$} & $t_{(43)}=-1.20$ & 0.24 & 0.03 \\
\hline HDL cholesterol (mg/dL) & 42.1 & 13.4 & {$[36.3-47.9]$} & 47.3 & 9.8 & {$[43.2-51.4]$} & $t_{(43)}=-1.48$ & 0.19 & 0.04 \\
\hline LDL cholesterol (mg/dL) & 99.5 & 19.9 & {$[86.9-112.1]$} & 108.2 & 25.9 & {$[99.3-117.1]$} & $t_{(43)}=-1.13$ & 0.22 & 0.03 \\
\hline Triglyceride (mg/dL) & 125.9 & 57.4 & {$[104.3-147.6]$} & 84.4 & 31.2 & {$[69.1-99.7]$} & $t_{(43)}=3.15$ & $* *$ & 0.19 \\
\hline Glycemia (mg/dL) & 89.7 & 8.5 & {$[81.9-97.4]$} & 91.9 & 17.2 & {$[86.3-97.4]$} & $t_{(43)}=-0.46$ & 0.57 & 0.00 \\
\hline
\end{tabular}




\begin{tabular}{|c|c|c|c|c|c|c|c|c|c|}
\hline & & & & & & & & \multicolumn{2}{|c|}{ (Conclusão) } \\
\hline & \multicolumn{2}{|c|}{$\begin{array}{c}\text { G1-NAFLD }(\mathrm{n}= \\
15)\end{array}$} & CI 95\% & \multicolumn{2}{|c|}{ G2 $(\mathrm{n}=30)$} & \multirow[t]{2}{*}{ CI 95\% } & \multirow[t]{2}{*}{ Test } & $p$ & $\begin{array}{l}\text { Effect } \\
\text { size }\end{array}$ \\
\hline & $M$ & $S D$ & & $M$ & $S D$ & & & & \\
\hline Energy (Kcal/dia) & $2,297.6$ & 427.2 & {$[2,119-2,476]$} & $2,340.2$ & 293.2 & {$[2,214-2,466]$} & $t_{(43)}=-0.39$ & 0.69 & 0.00 \\
\hline Carbohydrates (\%) & 49.5 & 6.6 & {$[46.4-52.5]$} & 46.1 & 5.4 & [43.9-48.3] & $t_{(43)}=1.81$ & 0.07 & 0.07 \\
\hline Lipids (\%) & 33.3 & 4.7 & {$[30.7-35.8]$} & 36.3 & 4.9 & {$[34.5-38.1]$} & $t_{(43)}=-2.01$ & $*$ & 0.08 \\
\hline Protein (\%) & 17.3 & 3.6 & {$[15.7-18.8]$} & 17.5 & 2.5 & {$[16.5-18.6]$} & $t_{(43)}=-0.29$ & 0.82 & 0.00 \\
\hline Fiber (g) & 7.8 & 2.7 & {$[5.5-10.1]$} & 9.0 & 4.9 & {$[7.4-10.6]$} & $t_{(43)}=-0.92$ & 0.29 & 0.02 \\
\hline Water intake ${ }^{(c)}$ & $N$ & $\%$ & & $N$ & $\%$ & & $\chi_{(1)}^{2}=1.60$ & 0.20 & 0.18 \\
\hline Adequate & 5 & 33.3 & {$[0.11-0.61]$} & 16 & 53.3 & {$[0.34-0.71]$} & & & \\
\hline Inadequate & 10 & 66.7 & {$[0.38-0.88]$} & 14 & 46.7 & [0.28-0.65] & & & \\
\hline Intestinal habit & & & & & & & $\chi_{(1)}^{2}=31.9$ & $*$ & 0.83 \\
\hline 1 or more times/day & 12 & 80 & {$[0.51-0.95]$} & 23 & 76.7 & {$[0.57-0.89]$} & & & \\
\hline Alternate days & 3 & 20 & {$[0.04-0.48]$} & 7 & 23.3 & {$[0.10-0.42]$} & & & \\
\hline
\end{tabular}

$* p \leq 0.05 ; * * p<0.01 ; * * * p<0.001$.

In the Food Pyramid (Figure 1), low or no food consumption at the base of the food pyramid (level 1) was observed, such as whole carbohydrates; consumption below the recommended level (fruits and vegetables); consumption close to the recommended level 3 (milk, dairy products and beans), and consumption above recommended level 4, which are oils, fats and simple sugars.

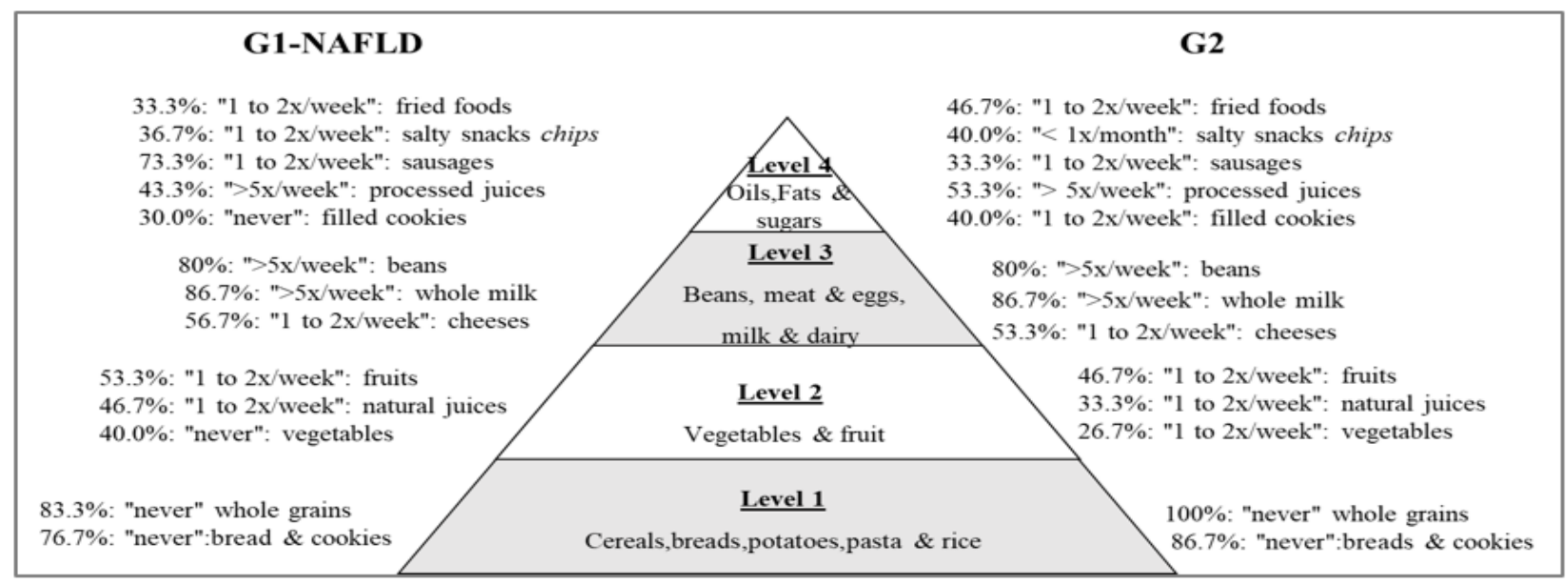

Figure 1. Frequency of consumption of food groups according to the Food Pyramid of the participants without $(\mathrm{n}=30)$ and with $(\mathrm{n}=15)$ NAFLD. Note: Recommended number of daily servings according to age group: level 1 (cereals, breads, potatoes, pasta and rice): 5 servings/day; level 2: 3 servings/day of vegetables and 3 servings/day of fruits; Level 3: 3 servings/day of milk or dairy products, 2 servings/day of meat and eggs and 1 serving/day of beans and level 4 (oils, fats and simple sugars): 1 serving / day (Brazilian Pediatric Society) 
Table 3. Family psychosocial risk of overweight children and adolescents with and without non-alcoholic fatty liver disease (NAFLD)

\begin{tabular}{|c|c|c|c|c|c|c|c|c|c|}
\hline \multirow[t]{2}{*}{ PAT 2.0 dimensions } & \multicolumn{2}{|c|}{$\begin{array}{c}\text { G1-NAFLD } \\
(\mathrm{n}=15)\end{array}$} & \multirow[t]{2}{*}{ CI 95\% } & \multicolumn{2}{|c|}{$\begin{array}{c}\text { G2 } \\
(\mathrm{n}=30)\end{array}$} & \multirow[t]{2}{*}{ CI 95\% } & \multirow[t]{2}{*}{ Test } & \multirow[t]{2}{*}{$p$} & \multirow[t]{2}{*}{$\begin{array}{c}\text { Effect } \\
\text { size }\end{array}$} \\
\hline & $M$ & $S D$ & & $M$ & $S D$ & & & & \\
\hline Family and resource structure & 0.34 & 0.16 & {$[0.24-0.32]$} & 0.27 & 0.18 & {$[0.20-0.33]$} & $t_{(43)}=1.24$ & 0.21 & 0.03 \\
\hline Social support & 0.17 & 0.31 & {$[0.01-0.31]$} & 0.12 & 0.28 & {$[0.00-0.22]$} & $t_{(43)}=0.54$ & 0.59 & 0.00 \\
\hline Child problems & 0.48 & 0.10 & {$[0.39-0.55]$} & 0.38 & 0.18 & {$[0.31-0.43]$} & $t_{(43)}=1.99$ & $*$ & 0.08 \\
\hline Sibling problems & 0.07 & 0.11 & {$[0.00-0.13]$} & 0.11 & 0.12 & {$[0.06-0.14]$} & $t_{(43)}=-0.94$ & 0.29 & 0.02 \\
\hline Family problems & 0.34 & 0.19 & {$[0.23-0.44]$} & 0.21 & 0.21 & {$[0.13-0.28]$} & $t_{(43)}=1.99$ & $*$ & 0.08 \\
\hline Parents' stress reactions & 0.37 & 0.32 & {$[0.22-0.52]$} & 0.21 & 0.28 & {$[0.09-0.31]$} & $t_{(43)}=1.81$ & 0.09 & 0.07 \\
\hline Family beliefs & 0.26 & 0.17 & {$[0.18-0.33]$} & 0.23 & 0.12 & {$[0.17-0.28]$} & $t_{(43)}^{(+3)}=0.72$ & 0.50 & 0.01 \\
\hline TOTAL score & 2.02 & 0.80 & {$[1.60-2.44]$} & 1.51 & 0.80 & {$[1.21-1.80]$} & $t_{(43)}=2.01$ & $*$ & 0.08 \\
\hline
\end{tabular}

$* p \leq 0.05$;

Table 4. Motivation and attitude scale regarding dietary treatment and practice of physical activity in overweight children and adolescents $(\mathrm{N}=45)$

\begin{tabular}{|c|c|c|c|c|c|c|c|c|c|}
\hline \multirow[t]{2}{*}{ Variable } & \multicolumn{2}{|c|}{$\begin{array}{c}\text { G1-NAFLD } \\
(\mathrm{n}=15)\end{array}$} & \multirow[t]{2}{*}{ CI 95\% } & & & \multirow[t]{2}{*}{ CI 95\% } & \multirow[t]{2}{*}{ Test } & \multirow[t]{2}{*}{$p$} & \multirow[t]{2}{*}{$\begin{array}{c}\text { Effect } \\
\text { size }\end{array}$} \\
\hline & $N$ & $\%$ & & $N$ & $\%$ & & & & \\
\hline Motivation - Dietary Treatment & & & & & & & 1.67 & 0.20 & 0.18 \\
\hline Yes & 13 & 86.7 & {$[0.54-0.98]$} & 29 & 96.7 & {$[0.82-0.99]$} & & & \\
\hline No & 2 & 13.3 & {$[0.01-0.40]$} & 1 & 3.3 & {$[0.00-0.17]$} & & & \\
\hline $\begin{array}{l}\text { Attitude Scale - Dietary Treat- } \\
\text { ment }\end{array}$ & & & & & & & 3.12 & 0.20 & 0.27 \\
\hline Nothing & 4 & 30.8 & {$[0.11-0.61]$} & 3 & 10.3 & {$[0.02-0.26]$} & & & \\
\hline Low & 7 & 53.8 & {$[0.26-0.78]$} & 17 & 58.6 & {$[0.40-0.77]$} & & & \\
\hline Moderate/High & 2 & 15.4 & {$[0.01-0.40]$} & 9 & 31.1 & {$[0.14-0.49]$} & & & \\
\hline Missing & 2 & & & 1 & & & & & \\
\hline $\begin{array}{l}\text { Motivation - Practice of Physical } \\
\text { Activity }\end{array}$ & & & & & & & 1.13 & 0.28 & 0.16 \\
\hline Yes & 7 & 46.7 & {$[0.21-0.73]$} & 19 & 63.3 & {$[0.43-0.80]$} & & & \\
\hline No & 8 & 53.3 & {$[0.26-0.78]$} & 11 & 36.7 & {$[0.19-0.56]$} & & & \\
\hline Attitude Scale - Physical Activity & & & & & & & 0.44 & 0.80 & 0.13 \\
\hline Low & 3 & 42.8 & {$[0.16-0.67]$} & 6 & 31.6 & {$[0.14-0.49]$} & & & \\
\hline Moderate & 2 & 28.6 & {$[0.07-0.55]$} & 8 & 42.1 & {$[0.25-0.62]$} & & & \\
\hline High & 2 & 28.6 & {$[0.07-0.55]$} & 5 & 26.3 & {$[0.13-0.46]$} & & & \\
\hline Missing & 8 & & & 11 & & & & & \\
\hline
\end{tabular}

Note: NAFLD = Non-alcoholic fatty liver disease. 


\section{DISCUSSION}

This study analyzed the clinical, anthropometric and dietary aspects of children and adolescents with overweight, and their motivation for treatment (diet and physical activity), their relationship with family psychosocial risk, comparing cases with (G1) and without NAFLD (G2). The mains results indicated that a higher prevalence of obesity (more than $80 \%$ ), and a third of the participants were diagnosed with NAFLD at a frequency higher than that found by Gobato et al. ${ }^{8}$ but within the mean for this age group ${ }^{6}$.

In our sample, the screen time was not different between the groups and similar results were found in the Brazilian ERICA study ${ }^{3}$. Physical activity was confined to school for half the sample, and $80 \%$ of them took physical education classes. The means to go to school also did not contribute to promote the physical activity, since the commute to the school was performed by motor vehicles for the majority of them. This daily practice could help, as some studies indicate that active transport to school (walking or cycling) are predictors of lower BMI and increased cardiovascular endurance during physical activity $^{12}$.

In anthropometric terms, all participants were above the cut-off point for waist circumference, with $20 \%$ being overweight and the other obese, with BMI mean values significantly higher for those of G1-NAFLD. In this study, there was a significant difference between the groups for neck circumference, and in BMI and waist circumference for G1-NAFLD, and our data are consistent with the study of Hatipoglu et al.?.

As regards to the clinical setting, almost $30 \%$ of the sample presented values above the reference for triglycerides, being significantly higher in G1-NAFLD. It is well documented that both overweight, as well as insulin resistance, harm the suppression of circulating free fatty acids in the postprandial period, which favors the entry of these free fatty acids into the hepatocytes with subsequent triglyceride synthesis ${ }^{13}$. In this sense, this prevalence of NAFLD is near than found in the study of Barros et al. ${ }^{7}$ to the adult population (32.3\%), but was different to found in the adolescents (8.4\%). It is noteworthy that all participants of this study had Type 1 diabetes and probably adolescents showed lower prevalence of NAFLD than adults due to shorter diabetes duration.

The carbohydrate intake means the frequency of the total sample was closer to the lower limit of the recommendation. It is interesting to observe the low fiber intake which indicates refined and straightforward sugars as the main sources of carbohydrates in the usual diet of the participants, especially among those in G1NAFLD, similarly to other studies ${ }^{13}$. Furthermore, the frequency of lipid intake in the sample was within the limits of the recommendation, but closer to the upper limit. A significant difference stood out for G1-NAFLD, with $60 \%$ higher than recommended intake, different to Papandreou et al. ${ }^{20}$. In the present study, there was a tendency for a higher percentage of lipid intake in G2; higher carbohydrate intake in G1-NAFLD and protein intake was similar among groups. Some authors observed that excessive carbohydrate intake is the main stimulus for hepatic lipogenesis and seems to contribute more directly to the onset of NAFLD than excessive lipid intake ${ }^{11}$.

Analyzing the frequency of higher prevalence for each food according to the Food Pyramid ${ }^{18}$, some food groups had a higher consumption rate. At level 2, for example, the daily consumption of vegetables was observed in the total sample and G1-NAFLD, showing intake below the recommendation and favoring a low food intake dietary profile with low-calories and high in fiber. At level 4, the consumption of ultra-processed foods of low nutritional value was highlighted. These data are similar to found in the study of Louzada et al. ${ }^{21}$, indicating a generalized trend of increased ultra-processed food consumption, especially in middle-income countries.

The PAT 2.0 showed that close to $40 \%$ of the families were at high psychosocial risk (Clinical), especially in the G1-NAFLD, while G2 presented lower levels, with a significant difference between the groups. These families had stressors linked to the child's problems, but fewer difficulties with the siblings and social support, which alleviates the risks ${ }^{13,19}$.

The motivation for treatment, in terms of diet and physical activity, was not different between G1-NAFLD and G2. However, both groups exhibited a contradiction between self-report of high motivation 
for treatment and low achievement of diet and exercise prescriptions. In the study by Dalla et al. ${ }^{12}$, the motivation for treatment was one of the main variables correlated to the reduction of BMI, corroborating the influence of psychosocial variables.

\section{CONCLUSION}

Children and adolescents with NAFLD have a more severe profile insofar as they have higher BMI and poorer dietary quality. Lifestyle changes are the first line of treatment. However, the adherence and consequent effectiveness were small, especially in NAFLD cases, which presented low motivation to diet and physical activity, as well as higher family psychosocial risk.

Age range, self-report of food consumption assessment tools and time limitation for data collection were limitations for this study. However, it is interesting to observe its clinical characteristics and that the data found allow comparisons consistent with the literature.

\section{ACKNOWLEDGMENTS}

The authors are thankful to PUC-Campinas (master's scholarship for the first author in Graduate Program in Health Sciences).

\section{CONFLICTS OF INTERESTS}

The authors declare no conflicts of interest.

\section{REFERENCES}

1. Afshin A, Reitsma MB, Murraj CJL. Health effects of overweight and obesity in 195 countries over 25 years. N Engl J Med 2017;377:13-27.

2. IBGE (Instituto Brasileiro de Geografia e Estatística). Pesquisa de Orçamentos Familiares (POF) 20082009: antropometria e estado nutricional de crianças, adolescentes e adultos no Brasil. [Family Budget
Survey 2008-2009: anthropometry and nutritional status of children, adolescents and adults in Brazil] Rio de Janeiro: 2010.

3. Bloch KV, Klein CH, Szklo M, Kuschnir MCC, Abreu GA, Barufaldi LA, et al. ERICA: prevalências de hipertensão arterial e obesidade em adolescentes brasileiros [Hypertension and obesity prevalence among Brazilian adolescents]. Rev Saude Publica 2016;50:113.

4. Koot BGP, Groot ED, Van der Baan-Slootweg OH, Bohte AE, Nederveen AJ, Jansen PLM, et al. Nonalcoholic fatty liver disease and cardiovascular risk in children with obesity. Obesity 2015;23:1239-43.

5. Park MH, Falconer C, Viner RM, Kinra S. The impact of childhood obesity on morbidity and mortality in adulthood: A systematic review. Obes Rev 2012; 13:985-00

6. 6. Grupta R, Bhangoo A, Matthews NAV, Anhalt H, Matta Y, Lamichhane B, et al. The prevalence of non-alcoholic fatty liver disease and metabolic syndrome in obese children. J Pediatr Endocrinol Metab 2011;24:907-11.

7. Barros BSV, Santos DC, Pizarro MH, Melo MGM, Gomes MB. Type 1 diabetes and non-alcoholic fatty liver disease: when should we be concerned? A Nationwide Study in Brazil. Nutrients 2017;9(8):878.

8. Gobato AM, Vasques ACJ, Yamada RM, Zambom MP, Barros-Filho AA, Hessel G. Indicadores bioquímicos, antropométricos e de composição corporal como preditores da esteatose hepática em adolescentes obesos [Biochemical, anthropometric and body composition indicators as predictors of hepatic steatosis in obese adolescents]. Rev. paul. pediatr 2014;32:230-36.

9. Hatipoglu N, Dogan S, Mazıcıoglu MM, Kurtoglu S. Relationship Relationship between neck circumference and non-alcoholic fatty liver disease in childhood obesity. J Clin Res Pediatr Endocrinol 2016;8:32-9.

10. Santos DMG, Ribas SA. Dieta e fatores de risco para doença cardiovascular em escolares adolescentes: 
estudo transversal [Diet and risk factors for cardiovascular disease in adolescent students: a cross-sectional study]. Adolesc Saude 2018;15:56-64.

11. Besaranoglu M, Besaranoglu G, Bugianesi E. Carbohydrate intake and nonalcoholic fatty liver disease: Fructose as a weapon of mass destruction. Hepatobiliary Surg Nutr 2015;4:109-16.

12. Dalla VM, Laatikainen T, Lehikoinen M, Nykänen P, Jääskeläinen J. Paediatric obesity treatment had better outcomes when children were younger, well-motivated and did not have acanthosis Nigricans. Acta Paediatrica 2017; 106:1842-50.

13. Wang Y, Lim, H. The global childhood obesity epidemic and the association between socio-economic status and childhood obesity. Int Rev Psychiatry 2012;24:176-88.

14. de Onis M, Onyango AW, Borghi E, Siyam A, Nishida C, Siekmann J. Development of a WHO growth reference for school-aged children and adolescents. Bull World Health Organ 2007;85:660-67.

15. Neuschwander-Tetri BA. Nonalcoholic steatohepatitis: An evolving diagnosis. Can J Gastroenterol Hepatol 2000; $14: 321-6$

16. Sociedade Brasileira de Cardiologia. V Diretriz Brasileira de Dislipidemias e Prevenção de Aterosclerose [V Brazilian Guideline on Dyslipidemias and Prevention of Atherosclerosis]. Arq Bras Cardiol 2013; 101:1-22.

17. National Research Council. Recommended dietary allowances. Washington, DC: National Academy Press: 1989.

18. Sociedade Brasileira de Pediatria (SBP). Manual de orientação para a alimentação do lactente, do pré-escolar, do escolar, do adolescente e na escola [Guidance manual for infant, pre-school, school, adolescent and school feeding]. Rio de Janeiro; 2012. p. 148.

19. Santos SS. Adaptação transcultural e validação do Psychosocial Assessment Tool (PAT2.0): instrumento de avaliação psicossocial de famílias de pacientes pediátricos recém-diagnosticados com câncer [Cross-cultural adaptation and validation of the Psy- chosocial Assessment Tool (PAT2.0): a psychosocial evaluation instrument of families of pediatric patients newly diagnosed with câncer]. 2012. (Dissertação) - Fundação Antônio Prudente.

20. Papandreou D, Karabouta Z, Pantoleon A, Rousso I. Investigation of anthropometric, biochemical and dietary parameters of obese children with and without non-alcoholic fatty liver disease. Appetite 2012;59:939-44.

21. Louzada MLC, Martins APB, Canella DS, Baraldi LG, Levy RB, Claro RM, et al. Alimentos ultraprocessados e perfil nutricional da dieta no Brasil [Ultra-processed foods and dietary nutritional profile in Brazil]. Rev Saude Publica 2015;49:38-49.

Recebido em: 05/02/2019

Aceito em: 16/06/2019 